\title{
EVALUASI PENERAPAN SISTEM AKUNTANSI PENGELUARAN KAS PENGGAJIAN PEGAWAI NEGERI SIPIL DI BADAN DIKLAT PROVINSI SULAWESI UTARA
}

\author{
Virginia Rebecka Golose \\ David P.E Saerang \\ Harijanto Sabijono \\ Fakultas Ekonomi dan Bisnis, Jurusan Akuntansi \\ Universitas Sam Ratulangi Manado \\ e-mail: virginrebecka@yahoo.com
}

\begin{abstract}
ABSTRAK
Dalam sistem akuntansi pengeluaran kas diperlukan adanya prosedur yang baik dan sesuai dengan kebijakan yang telah ditetapkan. Pengeluaran kas yang dilakukan di luar prosedur yang telah ditentukan, akan kemungkinan terjadinya penyelewengan, pencurian, dan penggelapan kas. Sehingga dapat dikatakan bahwa semakin baik sistem dan prosedur akuntansi pengeluaran kas yang dilakukan maka akan semakin dapat di percaya besarnya akun kas pada laporan keuangan tersebut.

Masalah dalam penelitian ini yaitu bagaimanakah Sistem Akuntansi Pengeluaran Kas khususnya pembayaran gaji Pegawai Negeri Sipil di Badan Diklat Provinsi Sulawesi Utara.

Tujuan penelitian ini untuk mengevaluasi penerapan sistem akuntansi pengeluaran kas, proses pembayaran gaji pegawai negeri sipil di Badan Diklat Provinsi Sulawesi Utara.

Penelitian ini adalah jenis penelitian deskriptif dengan menggunakan metode kualitatif. Dimana suatu analisis yang mengumpulkan, menyusun, dan mengolah, agar dapat memberikan gambaran mengenai suatu keadaan tertentu sehingga dapat ditarik kesimpulan.

Berdasarkan hasil penelitian menunjukkan bahwa sistem akuntansi pengeluaran kas pada Badan Diklat Provinsi Sulawesi Utara secara umum baik sesuai dengan permendagri No.13 Tahun 2006.
\end{abstract}

Kata Kunci : Sistem akuntansi Pengeluaran Kas.

\section{ABSTRACT}

In the accounting system cash outlay necessary to procedure well and in accordance with established policy cash expenditures made outside the prescribed procedure, the possibility of fraud, theft, and embezzlement cash. So that can be said that the better expenditure accounting systems and procedures cash will be able to do it in the trust account the amount of cash in the financial statement.

The problem in this study is How the implementation process payroll payments to the Civil Service Training Agency of North Sulawesi.

The purpose of this study to evaluate the application of the accounting system cash expenditures, the payment of salaries of civil servants in the province of North Sulawesi training agency.

This study is a descriptive research using qualitative methods in which an analysis is collecting, collating, and processing, in order to provide an overview of a particular state so that it can be deduced.

Based on the results of the study indicate that the accounting. System is cash expenditure on Training Agency of North Sulawesi is generally well under Permendagri Number. 13 of 2006.

Keywords: Accounts Payable Accounting System 


\section{Latar Belakang}

\section{PENDAHULUAN}

Pertumbuhan ekonomi dan perkembangan dizaman era global menuntut seluruh perusahaan untuk memperoleh keuntungan yang maksimal. Terutama dalam sistem informasi akuntansi yang dipergunakan secara efektif dan efisien. Penanganan dalam hal ini pengeluaran kas merupakan suatu aktifitas dalam perusahaan yang tidak mungkin dapat dilepaskan.

Pada perusahaan haruslah berhati-hati dalam melakukan aktifitas yang berhubungan dengan penerimaan dan pengeluaran kas, artinya setiap penerimaan dan pengeluaran kas yang dilakukan harus diperhitungkan manfaat dan keuntungan yang akan didapat. Untuk mendapatkan hasil yang maksimal, maka setiap perusahaan harus mempunyai kualitas sistem informasi akuntansi yang baik dari segi pendidikan, keahlian atau pun keterampilan dalam melaksanakan tugasnya. Dengan adanya sistem informasi akuntansi yang benar, maka manajemen dalam organisasi perusahaan dapat mengevaluasi hasil dari suatu operasi atau suatu kegiatan apakah berjalan dengan efisien dan efektif. Selain itu sistem informasi akuntansi dapat digunakan sebagai pedoman dalam penugasan dan wewenang bagi sumber daya manusia yang bekerja dalam organisasi atau perusahaan tersebut, sehingga dapat berjalan sesuai prosedur. Dengan adanya sistem informasi akuntansi, penyajian informasi yang sangat dibutuhkan tersebut bisa dengan cepat didapat, tepat waktu, akurat, dan relevan. Pengeluaran kas harus dilaksanakan secara efektif dan efisien agar tidak terjadi pemborosan anggaran. Sistem akuntansi pengeluaran kas merupakan sistem yang digunakan untuk mencatat seluruh transaksi pengeluaran kas. Penatausahaan pengeluaran kas merupakan serangkaian proses kegiatan menerima, menyimpan, menyetor, membayar, menyerahkan, dan mempertanggungjawabkan pengeluaran uang yang berada dalam pengelolaan SKPKD (Satuan Kerja Pengelolaan Keuangan Daerah) dan/atau SKPD (Satuan Kerja Perangkat Daerah).

Sistem dan prosedur akuntansi pengeluaran kas kususnya keuangan daerah merupakan serangkaian tahap dan langkah yang harus dilalui dalam melakukan fungsi akuntansi tertentu. Sistem dan prosedur akuntansi yang terdapat di pemerintahan daerah meliputi:

1. Sistem dan prosedur penerimaan kas

2. Sistem dan prosedur pengeluaran kas

3. Sistem dan prosedur akuntansi selain kas

4. Sistem dan prosedur akuntansi aset

(Mahmudi:Analisis Laporan Keuangan Pemerintah Daerah)

Berdasarkan uraian diatas, maka pemerintah daerah mempunyai peran yang sangat penting dalam pelaksanaan penggajian Pegawai Negeri Sipil di daerahnya. Untuk mengetahui sistem penerapan pelaksanaan penggajian pegawai negeri sipil tersebut. Yaitu Badan Diklat sebagai Satuan Kerja Perangkat Daerah (SKPD) pada Pemerintah Daerah wajib menyusun laporan pertanggungjawaban dengan menggunakan sistem akuntansi yang di atur oleh pemerintah daerah dalam bentuk Peraturan Gubernur yang bersifat mengikat. Dalam hal ini proses penggajian terpusat di Badan Pengelolaan Keuangan dan Barang Milik Daerah (BPKBMD) Provinsi Sulawesi Utrara. Dalam pelaksanaan proses pembayaran gaji terdapat permasalahan yaitu masih kurang optimalnya proses pembayaran (manual) yang berimbas pada ketidaktepatan waktu pembayaran.

\section{Tujuan Penelitian}

Tujuan penelitian ini adalah untuk mengevaluasi penerapan sistem akuntansi pengeluaran kas khususnya pembayaran gaji pegawai negeri sipil di Badan Diklat Provinsi Sulawesi Utara.

\section{Akuntansi}

\section{TINJAUAN PUSTAKA}

American Institute of Certified Public Accountant yang di kutib Muhammad (2002:11) mendefinisikan sebagai berikut "akuntansi adalah seni pencatatan, penggolongan, dan pengikhtisaran dengan cara tertentu dan dalam ukuran moneter, transaksi dan kejadian-kejadian yang umumnya bersifat keuangan dan termasuk menafsirkan hasil-hasilnya

\section{Akuntansi Pemerintahan}

Menurut Revrisond, Baswir (2000:7), Akuntansi Pemerintahan (termasuk akuntansi untuk lembaga non profit pada umumnya) merupakan bidang akuntansi yang berkaitan dengan lembaga pemerintahan dan lembaga-lembaga yang bertujuan untuk tidak mencari laba. Walaupun lembaga pemerintah senantiasa berukuran besar, namun sebagaimana dalam perusahaan ia tergolong sebagai lembaga mikro. 


\section{Sistem Akuntansi Pengeluaran Kas}

Mulyadi (2001:2). Setiap sistem dibuat untuk menangani sesuatu yang berulangkali atau secara rutin terjadi. Sedangkan akuntansi berasal dari kata "to Account" yang berarti "memperhitungkan".Dengan kata lainakuntansi adalah serangkaian kerja yang dimulai dari transaksi sampai membuat laporan keuangan yang berguna untuk pemakai laporan keuangan tersebut. Adapun sistem akuntansi adalah organisasi formulir, catatan dan laporan yang dikoordinasikan sedemikian rupa untuk menyediakan informasi keuangan yang dibutuhkan oleh managemen untuk menentukan kebijakan dalam pengelolaan kinerja perusahaan. Mulyadi (2001:3). Padapengertian sistem akuntansi tentu terkandung unsur-unsur seperti formulir, catatan yang terdiri dari jurnal, buku besar, buku pembantu dan laporan.

\section{Sistem Penggajian Pegawai Negeri Sipil}

Menurut Armstrong dan Murlis (1994:16) bahwa system penggajian adalah proses yang menentukan tingkat penggajian staf, memonitornya dan mengendalikan nya. Sampai saat ini belum ada teori atau ilmu yang pasti member acuan tentang pemberian gaji atau upah. Hal ini disebabkan karena masalah penggajian menyangkut dua kepentingan yang berbeda antara pegawai dan perusahaan dan sifatnya sangat kondisional.

\section{Konsep SKPD (Satuan Kerja Perangkat Daerah)}

Setiap SKPD yang mempunyai kewenangan untuk memungut dan atau menerima pendapatan daerah sesuai dalam Dokumen Pelaksanaan Anggaran (DPA) wajib melaksanakan pemungutan dan atau penerimaan berdasarkan ketentuan yang ditetapkan dalam peraturan perundang-undangan.

Pendapatan daerah melalui SKPD dilarang digunakan secara langsung untuk membiayai pengeluaran, kecuali di tentukan lain oleh peraturan perundang-undangan. Penerimaan pendapatan daerah berupa uang atau cek harus disetor ke rekening kas umum daerah paling lama satu hari kerja. Menurut permendagri Nomor 900/316/BAKD tentang pedoman sistem dan prosedur penatausahaan dan akuntansi, pelaporan, dan pertanggungjawaban keuangan daerah, berikut adalah pihak-pihak yang terkait dalam penatausahaan beserta tugas dan wewenangnya.

1. PPKD (Pejabat Pengelola Keuangan Daerah) berwenag untuk menetapkan Surat Ketetapan Pajak Daerah (SKP-Daerah)

2. Pengguna Anggaran berwenang untuk:

a. Menetapkan Surat Ketetapan Restribusi Daerah (SKR-Daerah)

b. Menerima dan mengesahkan Laporan pertanggungjawaban dari bendahara penerimaan melalui PPK SKPD.

c. PPK (Pejabat Penatausahaan Keuangan) SKPD berwenang untuk melakukan verifikasi atas penerimaan harian yang diterima dan dibukukan oleh bendahara penerimaan.

3. Bendahara Penerimaan SKPD dimana me miliki kewenangan sebagai berikut.

a. Menerima pembayaran sejumlah uang yang tetera pada SKPD/SKR-Daerah .

b. Memverifikasikan kesesuaian jumlah uang yang diterima dengan dokumen SKP-Daerah Yang diterimanya dari PPKD

c. Memverifikasikan kesesuaian jumlah uang yangditerima dengan dokumen SKR yang diterimanya dari pengguna anggaran.

d. Membuar Surat Tnada Setoran (STS) dan Surat Tanda Bukti Pembayaran/Bukti lain yang sah.

e. Menyerahkan Tanda Bukti Pembayaran.

f. Menyerahkan STS beserta uang yang diterimanya pada rekening bank Kas Umum daerah.

g. Mendokumentasikan daftar STS dalam register STS

h. Membukukan penerimaan pendapatan daerah dengan menggunakan buku Penerimaan dan Penyetoran bendahara penerima.

i. Membuat dan menyampikan laporan pertanggunjawaban penerima administratif kepada pengguna anggaran melalui PPK SKPD.

4. Bendahara Penerimaan Pembantu SKPD

5. PPKD selaku BUD (Bendahara Umum Derah) 


\section{Konsep SKPKD (Satuan Kerja Pengelolaan Keuangan Daerah)}

Menurut Permendagri No.13 Tahun 2006 Pasal 1 Satuan Kerja Pengelola Keuangan Daerah selaku pengguna anggaran/pengguna barang, yang juga melaksanakan pengelolaan keuangan daerah.Dalam kegiatannya, SKPKD dipimpin oleh Pejabat Pengelola Keuangan Daerah (PPKD) yang mempunyai tugas melaksanakan pengelolaan APBD dan bertindak sebagai Bendahara Umum Daerah (BUD).

Penerimaan yang dikelola PPKD berupa pendapatan dana perimbangan,pendapatan lain-lain yang sah, dan pembiayaan penerimaan. Penerimaan-penerimaan tersebut diterima secara langsung di rekening Kas Umum Daerah. Untuk mengelola penerimaan tersebut, dapat ditunjuk bendahara penerimaan PPKD. Sesuai permendagri No55 Tahun 2008 Pasal 1, bendahara penerimaan PPKD adalah pejabat fungsional yang ditunjuk untuk menerima, menyimpan, menyetorkan, menatausahakan, dan mempertanggungjawabkan penerimaan uang yang bersumber dari transaksi PPKD.

Meskipun demikian, atas pertimbangan efisiensi dan efektivitas, tugas dan wewenang bendahara penerimaan PPKD dapat dirangkap oleh Bendahara Umum Daerah.

Sesuai Permendagri No 55 Tahun 2008 Pengajuan Surat Permintaan Pembayaran (SPP) yang dilakukan Bendahara Pengeluaraan PPKD adalah untuk melakukan belanja PPKD dan Pengeluaran Pembiayaan. Belanjabelanja PPKD tersebut antara lain belanja Hibah, belanja bunga, dan belanja tak terduga. Dalam melaksanakan tugas, bendahara pengeluaran PPKD berwenang untuk:

1. Mengajukan permintaan pembayaran menggunakan SPP-LS PPKD

2. Meneliti kelengkapan dokumen pendukung SPP-LS PPKD

3. Mengembalikan dokumen pendukung SPP-LS PPKD kepada pejabat terkait jika dokumen tersebut tidak memenuhi syarat dan/tidak lengkap.

Dalam Proses belanja PPKD dan pengeluaran pembiayaa, bendahara pengeluaran PPKD mengajukan dan menyusun dokumen SPP-LS PPKD.Selain dokumen SPP-LS itu sendiri, lampiran yang perlu di persiapkan dalam pengajuan SPP-LS antara lain:

1. Salinan SPD

2. Lampiran lain yang diperlukan

Disamping membuat SPP, bendahara pengeluaran PPKD juga membuat buku register untuk SPP yang diajukan, SPM, dan SP2D yang sudah diterima bendahara.

\section{Penelitian Terdahulu}

Tabel 1. Penelitian Terdahulu

\begin{tabular}{|c|c|c|c|c|c|c|}
\hline $\begin{array}{l}\text { Nama } \\
\text { Peneliti/ } \\
\text { Tahun }\end{array}$ & Judul & Tujuan & $\begin{array}{l}\text { Metode } \\
\text { Penelitian }\end{array}$ & Hasil Penelitian & Persamaan & Perbedaan \\
\hline $\begin{array}{l}\text { Tiura } \\
\text { Siahaan } \\
(2010)\end{array}$ & $\begin{array}{l}\text { Penerapan } \\
\text { Sistem } \\
\text { Penggajian } \\
\text { Pegawai } \\
\text { Negeri Sipil } \\
\text { di } \\
\text { Pemerintah } \\
\text { Kota Medan }\end{array}$ & $\begin{array}{l}\text { Bertujuan } \\
\text { bagaimana } \\
\text { cara } \\
\text { mengatasi } \\
\text { hambatan } \\
\text { yang timbul } \\
\text { dalam } \\
\text { pelaksanaan } \\
\text { Penggajian } \\
\text { Pegawai } \\
\text { Negeri Sipil } \\
\text { di Pemerintah } \\
\text { Kota Medan }\end{array}$ & $\begin{array}{l}\text { Pengemba } \\
\text { ngan } \\
\text { deskriptif } \\
\text { dengan } \\
\text { jenis } \\
\text { penelitian } \\
\text { empiris }\end{array}$ & $\begin{array}{l}\text { Penerapan sistem } \\
\text { penggajian belum } \\
\text { memadai sehingga } \\
\text { menyebabkan } \\
\text { ketidakpaduan sistem }\end{array}$ & $\begin{array}{l}\text { Peneliti } \\
\text { sebelumnya } \\
\text { melakukan } \\
\text { penelitian } \\
\text { terhadap faktor } \\
\text { yang sama } \\
\text { memerlukan } \\
\text { penerapan sistem } \\
\text { yang tepat untuk } \\
\text { gaji Pegawai } \\
\text { Negeri Sipil }\end{array}$ & $\begin{array}{l}\text { Metode analisis } \\
\text { sebelumnya } \\
\text { menggunakan } \\
\text { metode analisis } \\
\text { deskriptif } \\
\text { dengan jenis } \\
\text { penelitian } \\
\text { empiris } \\
\text { sedangkan } \\
\text { peneliti } \\
\text { menggunakan } \\
\text { jenis penelitian } \\
\text { deskriptif } \\
\text { dengan metode } \\
\text { kualitatif. }\end{array}$ \\
\hline
\end{tabular}




\begin{tabular}{lllllll}
\hline Intan & Pelaksanaan & Bertujuan & Bersifat & Pelaksanaan & Terjadi & Peneliti \\
Hapsari & Sistem & menganalisis & deskriptif & Penggajian Pegawai & keterlambatan & terdahulu \\
(2011) & Penggajian & bagaimanakah & dengan & Negeri Sipil di & dalam & menggunakan \\
& Pegawai & pelaksanaan & jenis & Pemerintah Kota & ketidaktepatan & metode analisis \\
& Negeri Sipil & Penggajian & penelitian & Surakarta sudah sesuai & waktu & deskriptif jenis \\
& di & Pegawai & empiris & dengan peraturan & pembayaran gaji & penelitian \\
& Pemerintah & Negeri Sipil & & perundang-undangan & Pegawai Negeri empiris & eman \\
& Kota & di Pemerintah & & yang berlaku. & Sipil . & sedangkan \\
& Surakarta & Kota & & & & peneliti \\
& & Surakarta & & & & menggunakan \\
& & & & & analisis \\
deskriptif \\
\end{tabular}

\section{Jenis Penelitian}

\section{METODE PENELITIAN}

Jenis penelitian ini adalah penelitian deskriptif untuk memberikan gambaran secara sistematis dan akurat mengenai fakta, sifat dari hubungan antar fenomena yang diteliti pada objek penelitian. Gambaran yang sistematis dan akurat diperoleh dengan mengumpulkan, mengklasifikasikan data sehingga akan memberikan hasil yang konkrit pada permasalahan dan kemudian dilaksanakan analisis sehingga dapat ditarik kesimpulan.

\section{Tempat dan Waktu penelitian}

Penelitian ini dilakukan pada Badan Diklat Provinsi Sulawesi Utara. Jl.Walanda Maramis KM.10 Watutumou Maumbi, Minahasa Utara. Instansi ini sebagai Badan Pendidikan dan Pelatihan sebagai sumberdaya aparatur di lingkungan pemerintahan. Lamanya waktu penelitian sekitar 1 bulan, yaitu pada bulan November.

\section{Prosedur Penelitian}

Penulis melakukan kajian awal dengan melakukan studi literatur baik studi kepustakaan maupun membaca melalui internet.Kemudian diperoleh dengan mengumpulkan, pengidentifikasian tentang masalah, merumuskannya, menetapkan tujuan/ manfaat penelitian, dan kemudian dilaksanakan evaluasi sehingga dapat ditarik kesimpulan. Kemudian membatasi masalah ke lingkup yang disesuaikan dengan penelitian saat ini. Perancangan dan persiapan survei pada objek penelitian yang telah ditentukan, kemudian pengumpulan data baik primer maupun sekunder.

\section{Metode Pengumpulan Data}

Jenis Data dibedakan atas dua, yaitu data kualitatif dan data kuantitatif. Kuncoro (2007:124)

a. Data Kualitatif

Data kualitatif merupakan data yang tidak berbentuk angka (numerik) yang diperoleh dari rekaman, pengamatan, wawancara, atau bahan tertulis.

b. Data Kuantitatif

Data kuantitatif merupakan data yang berbentuk angka diperoleh dari penjumlahan atau pengukuran.

Jenis data yang di gunakan penulis dalam penelitian ini adalah jenis data kualitatif. Bersumber dari lokasi penelitian yang diperoleh melalui wawancara dan tanya jawab dengan kepala badan diklat dan pegawai negeri sipil sebagai bendahara pengeluaran yang terkait dengan objek penelitian serta penelitian secara langsung mengenai siklus kerja dalam badan diklat yang terkait dengan penelitian. Disajikan tidak dalam bentuk angkaangka. 


\section{Sumber Data}

Sumber Data dibedakan atas dua,yaitu data primer dan data sekunder. Hasan (2008:19).

a. Data primer, merupakan sumber data penelitian yang diperoleh secara langsung dari sumber asli (tidak melalui medis prantara). Data primer dapat berupa subjek (orang) secara individual/kelompok, kejadian/kegiatan dan hasil-hasil pengujian.

b. Data sekunder, merupakan sumber data penelitian yang diperoleh peneliti secara tidak langsung melalui media perantara (di peroleh dan di catat oleh pihak lain). Data sekunder umumnya berupa bukti, catatan, atau laporan yang telah tersimpan dalam arsip yang dipublikasikan dan yang tidak di publikasikan.

Sumber Data yang digunakan dalam penelitian ini adalah data primer. Dalampenelitian ini data di ambil dari kantor badan diklat provinsi sulawesi utara.

\section{Metode Analisis}

Dari data yang diperoleh, maka dilakukan analisa data agar dapat diinterpretasikan. Metode analisa data yang digunakan dalam penelitian ini adalah analisa deskriptif kualitatif. Analisa deskriptif kualitatif merupakan data yangtidak berbentuk angka (numerik) yang diperoleh melalui wawancara dan Tanya jawab dengan kepala badan diklatdan pegawai negeri sipil sebagai bendahara pengeluaran. Disajikan tidak dalam bentuk angka-angka.

\section{Hasil Penelitian}

\section{HASIL PENELITIAN DAN PEMBAHASAN}

\section{Gambaran Umum Badan Diklat Provinsi Sulawesi Utara}

Meningkatkan kualitas Sumber Daya Manusia termasuk didalamnya Sumber Daya Aparatur sebagai kunci utama pembangunan yang ditunjang dengan Kearifan Lokal yang menyatu dalam ikatan keterpaduan, kekompakan dan persaudaraan sebagai kekuatan untuk membangun daerah merupakan salah satu bagian penting yang harus dilakukan.

Badan Pendidikan dan Pelatihan Provinsi Sulawesi Utara sebagai salah satu Unsur Pelaksana sesuai tugas pokok dan fungsinya, harus mampu menopang kebijakan pembangunan Sulawesi Utara tersebut dengan peningkatan profesionalisme,disiplindan produktivitas aparatur melalui pelaksanaan serangkaian Kegiatan Kediklatan.

\section{Visi dan Misi Badan Diklat Provinsi Sulawesi Utara}

\section{A. Visi}

Badan Pendidikan dan Pelatihan Provinsi Sulawesi Utara dalam menjawab tuntutan kerja secara internal maupun eksternal dan dalam mengantisipasi tantangan di masa akan datang, menetapkan Visi:

\section{"Mewujudkan Badan Diklat Provinsi Sulawesi Utara Sebagai Pusat Peningkatan Kualitas Sumber Daya Aparatur Daerah".}

\section{B. Misi}

Untuk mewujudkan Visi Badan Pendidikan dan Pelatihan Provinsi Sulawesi Utara tersebut, dirumuskan Misi sebagai berikut:

1. Meningkatkan kualitas Tenaga Kediklatan

2. Meningkatkan kualitas dan kuantitas penyelenggaraan Pendidikan dan Pelatihan Aparatur

3. Meningkatkan kualitas sarana, prasarana diklat

\section{Sistem dan Prosedur Pengeluaran Kas Penggajian}

Surat Pertanggungjawaban (SPJ) merupakan dokumen yang menjelaskan penggunaan dari dana-dana yang dikelola oleh Bendahara Pengeluaran. SPJ juga merupakan laporan keuangan yang dihasilkan oleh sebuah sistem tata buku tunggal yang dilaksanakan oleh bendahara Pengeluaran.

Permendagri 13/2006 (pasal 220 sampai 227) memberikan panduan pelaksanaan penyusunan dokumen SPJ. Deskripsi Kegiatan 
Bendahara pengeluaran secara administratif wajib mempertanggungjawabkan penggunaan uang persediaan/ganti uang persediaan/tambah uang persediaan kepada kepala SKPD melalui PPK-SKPD paling lambat tanggal 10 bulan berikutnya.

Dalam mempertanggungjawabkan pengelolaan uang persediaan, dokumen laporan pertanggungjawaban yang disampaikan mencakup:

a. Buku kas umum pengeluaran.

b. Ringkasan pengeluaran per rincian obyek yang disertai dengan bukti-bukti pengeluaran yang sah atas pengeluaran dari setiap rincian obyek yang tercantum dalam ringkasan pengeluaran per rincian obyek dimaksud.

c. Bukti atas penyetoran PPN/PPh ke kas negara.

d. Register penutupan kas.

Dalam melakukan verifikasi atas laporan pertanggungjawaban yang disampaikan, PPK-SKPD berkewajiban:

a. Meneliti kelengkapan dokumen laporan pertanggungjawaban dan keabsahan bukti-bukti pengeluaran yang dilampirkan;

b. Menguji kebenaran perhitungan atas pengeluaran per rincian obyek yang tercantum dalam ringkasan per rincian obyek

c. Menghitung pengenaan $\mathrm{PPN} / \mathrm{PPh}$ atas beban pengeluaran per rincian obyek dan menguji kebenaran sesuai dengan SPM dan SP2D yang diterbitkan periode sebelumnya.

Dokumen yang digunakan oleh PPK-SKPD dalam menatausahakan pertanggungjawaban pengeluaran mencakup:

1. Register penerimaan laporan pertanggungjawaban pengeluaran (SPJ);

2. Register pengesahan laporan pertanggungjawaban pengeluaran (SPJ);

3. Surat penolakan laporan pertanggungjawaban pengeluaran (SPJ);

4. Register penolakan laporan pertanggungjawaban pengeluaran (SPJ);

5. Register penutupan kas.

$\underline{\text { Pihak Terkait }}$

1. Bendahara Pengeluaran

Dalam kegiatan ini, Bendahara Pengeluaran memiliki tugas sebagai berikut :

a. Menguji kebenaran dan kelengkapan dokumen pertanggungjawaban.

b. Melakukan pencatatan bukti-bukti pembelanjaan dana dari UP/GU/TU dan LS pada dokumen Buku pengeluaran, Buku Pembantu Simpanan/ Bank, Buku Pembantu Pajak, Buku Pembantu Panjar, dan Buku Pembantu Pengeluaran per objek.

c. Melakukan rekapitulasi pengeluaran dan mencatatnya dalam SPJ yang akan diserahkan ke Pengguna Anggaran (melalui PPK SKPD) untuk disahkan.

2. PPK-SKPD

Dalam kegiatan ini, PPK SKPD memiliki tugas sebagai berikut :

a. Menguji SPJ pengeluaran beserta kelengkapannya.

b. Meregister SPJ pengeluaran yang disampaikan oleh Bendahara pengeluaran dalam buku register penerimaan SPJ pengeluaran.

c. Meregister SPJ pengeluaran yang telah disahkan oleh Pengguna Anggaran ke dalam buku register pengesahan SPJ pengeluaran.

d. Meregister SPJ pengeluaran yang telah ditolak oleh Pengguna Anggaran ke dalam buku register penolakan SPJ pengeluaran.

3. Pengguna Anggaran

Dalam kegiatan ini, Pengguna Anggaran memiliki tugas Menyetujui atau menolak SPJ pengeluaran yang diajukan oleh Bendahara.

\section{Sistem Dan Preosedur Akuntansi Pengeluaran Kas Penggajian}

Prosedur akuntansi pada SKPKD sebagai PA meliputi serangkaian proses mulai dari pencatatan, pengikhtisaran, sampai dengan pelaporan keuangan dalam rangka pertanggungjawaban pelaksanaan APBD yang dapat dilakukan secara manual atau menggunakan aplikasi komputer. Permendagri 13/2006 (pasal 266 sampai dengan 288) mengatur tentang hal terkait.

Deskripsi Kegiatan 
Akuntansi PPKD adalah sebuah entitas akuntansi yang dijalankan oleh fungsi akuntansi di SKPKD, yang mencatat transaksi-transaksi yang dilakukan oleh SKPKD dalam kapasitas sebagai Pemda. SKPKD adalah suatu satuan kerja yang mempunyai tugas khusus untuk mengelola keuangan daerah. SKPKD biasanya dikelola oleh suatu entitas tersendiri berupa Badan Pengelola Keuangan Daerah (BPKD).

Badan/Biro/Bagian Keuangan juga menyusun RKA-SKPKD selaku Pejabat Pengguna Anggaran. Kosekuensi atas keadaan ini adalah bahwa PPK-SKPKD hanya mengurusi masalah pendapatan/belanja untuk satuan kerja saja.

Dalam pelaksanaan anggaran transaksi yang terjadi di SKPKD dapat diklasifikasikan menjadi dua yaitu:

1. Transaksi-transaksi yang dilakukan oleh SKPKD sebagai satuan kerja

2. Transaksi-transaksi yang dilakukan oleh SKPKD pada level Pemerintah Daerah seperti pendapatan dana perimbangan, bunga, subsidi, hibah, bantuan sosial, belanja bagi hasil, bantuan keuangan dan belanja tiga terduga. Termasuk transaksi-transaksi pembiayaan, pencatatan investasi dan hutang jangka panjang. akuntansi

Tata cara dan perlakuan akuntansi oleh SKPKD sebagai satuan kerja mengikuti tata cara dan perlakuan

Pada prosedur ini akan dijelaskan tata cara dan perlakuan akuntansi bagi SKPKD yang berfungsi merekam transaksi-transaksi oleh (pada level) pemerintah daerah.

Dengan demikian, prosedur ini akan meliputi:

1. Akuntansi Pendapatan (Dana Perimbangan dan Pendapatan Lainnya)

2. Akuntansi Belanja (belanja bunga, subsidi, hibah, bantuan sosial, belanja bagi hasil, bantuan keuangan dan belanja tidak terduga)

3. Akuntansi Pembiayaan

4. Akuntansi Aset (Investasi Jangka Panjang)

5. Akuntansi Hutang

6. Akuntansi Konsolidator

7. Akuntansi Selain Kas.

Sistem Akuntansi Pengeluaran kas penggajian pada Badan Diklat Provinsi Sulawesi Utara sesuai dengan Permendagri No 13 Tahun 2006 terdiri atas 4 sub sistem yaitu:

1. SPK

2. PPKD selaku BUD

3. SKPD

4. Bendahara Pengeluaran

5. Bank

Berikut ini akan disajikan sistem akuntansi pengeluaran kas penggajian pada Badan Diklat Provinsi Sulawesi Utara. 
Gambar 4.5.Flowchart Akuntansi Pengeluaran Kas Tahap IV

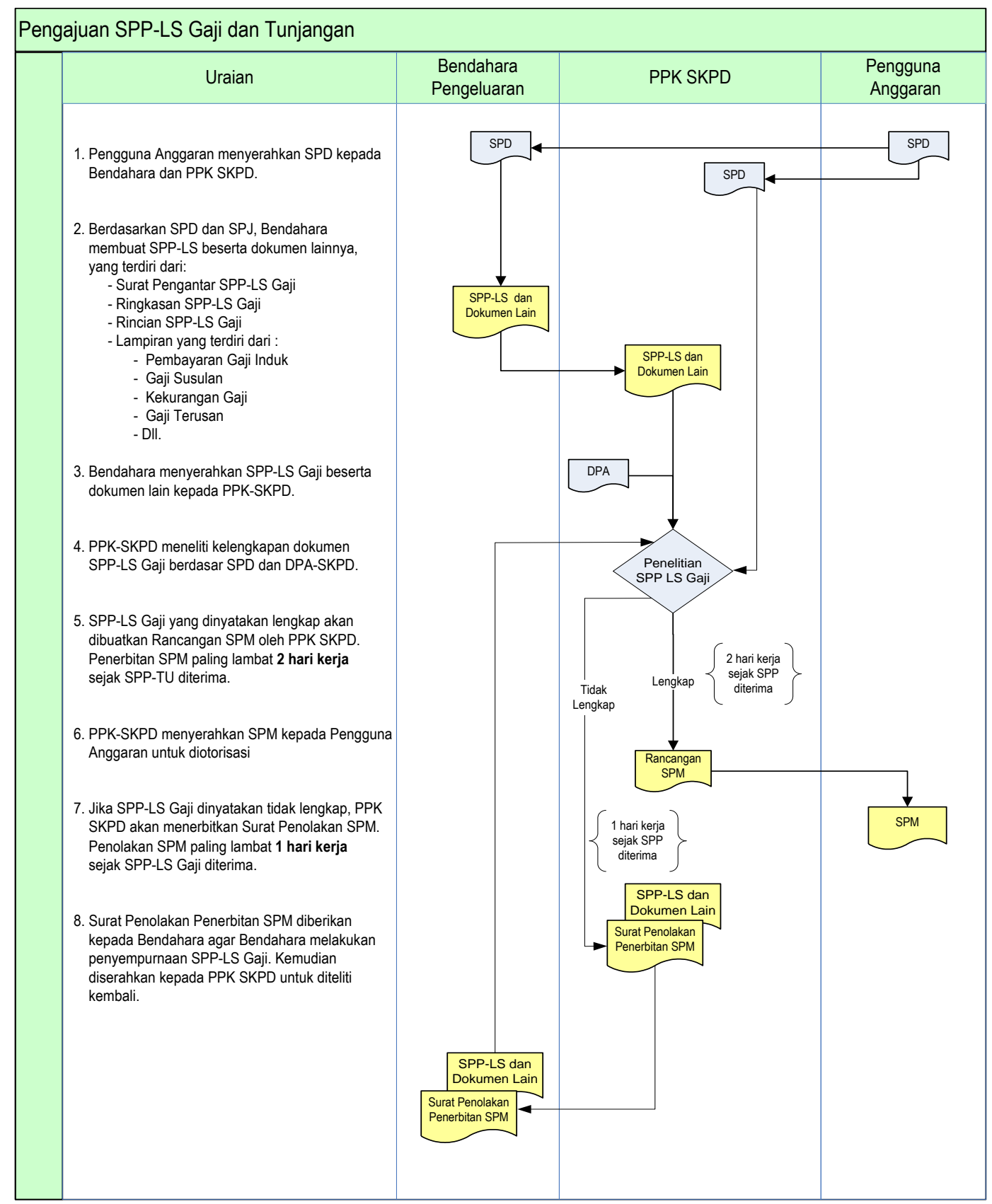




\section{Pembahasan}

Berdasarkan Flowchart mengenai sistem pelaporan akuntansi bahwa

1. Menjelaskan bahwa akuntansi pengeluaran kas penggajian pada Badan Diklat Provinsi Sulawesi Utarapengguna anggaran memberikan SPD kepada bendahara dan PPK SKPD

2. Mmenjelaskan bahwa Berdasarkan SPD dan SPJ,bendahara membuat SPP-LS beserta dokumen lainnya:

Surat SPP-LS Gaji

Ringkasan SPP-LS Gaji

Rincian SPP-LS

Lampiran yang terdiri dari: Pembayaran gaji induk,Gaji susulan, Kekurangan gaji,Gaji terusan.

3. Bendahara menyerahkan SPP-LS Gaji beserta dokumen lain kepada PPK-SKPD

4. PPK-SKPD meneliti kelengkapan dokumen SPP-LS gaji berdasar SPD dan DPA-SKPD

5. SPP-LS gaji dinyatakan lengkap akan dibuatkan rancangan SPM oleh PPK-SKPD penerbitan SPM paling lambat 2 hari kerja sejak SPP-TU diterima

6. PPK-SKPD menyerahkan SPM kepada pengguna anggaran untuk diotorisasi

7. Jika SPP-LS gaji dinyatakan tidak lengkap PPK-SKPD akan menerbitkan surat penolakan SPM.Penolakan SPM paling lambat 1 hari kerja sejak SPP-LS gaji diterima.

8. Surat Penolakan SPM diberikan kepada bendahara agar bendahara melakukan penyempurnaan SPP-LS gaji.Kemudia diserahkan kepada PPK-SKPD untuk diteliti kembali.

Sistem Akuntansi Pengeluaran Kas Penggajian Pegawai Negeri Sipil pada Badan Diklat Provinsi Sulawesi Utara berdasarka flowchart dokumen telah diterapkan dengan baik dan tertib,dan penerapannya sudah sesuai dengan karakteristik kualitatif laporan keuangan dan dilakukan secara sistematis, dimulai dari bendahara umum kemudian akan diotorisasi oleh SKPD Pengguna Anggaran yang kemudian akan dibuatkan surat untuk melakukan pembayaran yang diotorisasi oleh PPKD melalui input ke sistem komputerisasi,bendahara akan melakukan penerimaan tunai melalui bank, kemudian dicatat pada bagian akuntansi.

Badan Diklat Provinsi Sulawesi Utara sebagai unsur pendukung tugas Pemerintah Provinsi Sulawesi Utara yang bersifat spesifik dibidang pendidikan dan pelatihan meskipun sistem pencatatan maupun pelaporan akuntansinya sudah komputerisasi dengan menggunakan microsoft exel ,tetapi cara pemakaianya masi semi manual,dengan tidak menggunakan berbagai fasilitas yang ada pada microsoft exel.Namun segala bentuk pencatatan dan pelaporannya sudah memenuhi standar akuntansi sesuai dengan peraturan pemerintah yang ada.

Sistem Akuntansi Pengeluaran Kas Penggajian Pegawai Negeri Sipil di Badan Diklat Provinsi Sulawesi Utara sudah sesuai Permendagri No 13 Tahun 2006, karena informasi/data dapat dipertanggunjawabkan secara administratif,dan benar menurut kaidah standar akuntansi, aspek hukum dan aspek teknis manajemen dan keadaan database di pastikan penggunaannya secara fisik oleh Badan Diklat Provinsi Sulawesi Utara diterima umum karena adanya dokumen-dokumen dan bukti transaksi seperti: Surat Penyediaan Dana (SPD),Surat Permintaan Pembayaran (SPP), Surat Permintaan membayar (SPM), Surat Perintah Pencairan Dana (SP2D), Surat Pertanggungjawaban (SPJ) dan Nota Permintaan Dana (NPD).

Dilihat dari Gambar 4.5.Flowchart Akuntansi Pengeluaran Kas Tahap IV tentang Pengajuan SPP-LS Gaji dan Tunjangan dalam Sistem akuntansi yang sesuai aturan Permendagri No 13 tahun 2006.Adapun uraian yang dijelaskan pengguna anggaran telah memberikan SPD (Surat Pencairan Dana) kepada Bendahara Pengeluaran karena proses dari bendahara mengalami keterlambatan dalam pembuatan SPP-LS gaji untuk di berikan kepada PPK-SKPD dalam hal ini untuk pencairan dana.Dan karena terjadi kesalahan dalam proses penggajian diakibatkan karena adanya perubahan pangkat dan golongan sehingga terjadi kesalahan yang tidak sesuai dengan prosedur akuntansi yang ada dan untuk menyelesaikan di butuhkan dua hari kerja tetapi memakan waktu hingga 3 sampai empat hari sehingga dalam proses pembayaran gaji kepada Pegawai Negeri Sipil mengalami keterlambatan.

\section{Kesimpulan}

\section{PENUTUP}

Dari hasil analisis yang telah dilakukan,maka dapat diambilbeberapa kesimpulan tentang Sistem Akuntansi Pengeluaran Kas Penggajian Pegawai Negeri Sipil di Badan Diklat Provinsi Sulawesi Utara, khususnya pada Sub Bagian Perencanaan dan Keuangan sebagai berikut:

1. Sistem Akuntansi Pengeluaran Kas Penggajian Pegawai Negeri Sipil di Badan Diklat Provinsi Sulawesi Utara berdasarkan flowchart dokumen telah diterapkan dengan baik dan tertib, dan penerapannya sudah sesuai denga karakteristik kualitatif laporan keuangan dan dilakukan secara sistematis, dimulai dari 
Bendahara umum kemudian akan diotorisasi oleh SKPD Pengguna Anggaran, yang kemudian akan dibuatkan surat untuk melakukan pembayaran yang diotorisasi oleh PPKD, dan selanjutnya bendahara akan melakukan penerimaan tunai melalui bank, kemudian di catat pada bagian akuntansi dan di bayar atau di berikan secara tunai kepada pegawai sesuai dengan pangkat dan golongan pegawai itu sendiri.

2. Sistem Akuntansi Pengeluaran Kas Penggajian Pegawai Negeri Sipil di Badan Diklat Provinsi Sulawesi Utara sudah sesuai Permendagri No 13 Tahun 2006, karena informasi/data dapat dipertanggunjawabkan secara administratif, dan benar menurut kaidah standar akuntansi. Keadaan database di pastikan penggunaannya secara fisik oleh Badan Diklat Provinsi Sulawesi Utara diterima umum karenaadanya dokumen-dokumen dan bukti transaksi seperti: Surat Penyediaan Dana (SPD), Surat Permintaan Pembayaran (SPP),Surat Permintaan membayar (SPM),Surat Perintah Pencairan Dana (SP2D), Surat Pertanggungjawaban (SPJ) dan Nota Permintaan Dana (NPD)

3. Sistem Penggajian Pegawai Negeri Sipil Badan Diklat Provinsi Sulawesi Utara melalui SIMDA Penggajian.

\section{Saran}

Dikarenakan adanya tuntutan transparansi keuangan daerah sekarang ini, maka peneliti menyarankan agar sistem ini dilaksanakan secara efisien dan efektif dengan mengacu pada peraturan yang sudah ditetapkan. Selain itu ada saran yang ditawarkan oleh peneliti menyangkut pembahasan dalam skripsi ini.

1. Meningkatkan dan mempertahankan kualitas seorang Pegawai Negeri Sipil (PNS) karena mempunyai peranan amat penting sebab Pegawai Negeri Sipil merupakan unsur aparatur Negara.

2. Kebijaksanaan yang sudah digariskan atau ditetapkan kehendaknya dijadikan pedoman dan pengalaman dimasa yang akan datang serta memperhatikan prinsip-prinsip akuntansi yang berlaku umum.

3. Bidang akuntansi (bidang keuangan) harus lebih teliti dalam membuat laporan keuangan,untuk menghindarkan kesalahan akuntansi dalam pengeluaran kas penggajian dan pengeluaran kas lainnya.

4. Sistem Akuntansi Pengeluaran Kas Penggajian Pegawai Negeri Sipil Badan Diklat Provinsi Sulawesui Utara harus benar-benar dirancang sedemikian rupa dan dijalankan sesuai dengan fungsi dan tanggung jawabnya agar tidak terjadi keterlambatan dalam pembayaran gaji dan tidak terjadi kesalahan-kesalahan dalam pencatatan akuntansi.

\section{DAFTAR PUSTAKA}

Abdul Halim. 2002. Akuntansi Pemerintahan. Jakarta : Salemba Empat.

Armstrong, Murlis. 1994.System Penggajian. Yogyakarta : Salemba Empat.

Bachtiar Arif, Muchlis, Iskandar. 2002:3. Akuntansi Pemerintahan, Jakarta : Salemba Empat.

Balkaoui, Ahmed Riahi. 2000. Teori Akuntansi Edisi Pertama. Penerbit Salemba Empat: Jakarta.

Bawono,Tata cara Penatausahaan dan Pertanggungjawaban Bendahara pada SKPD dan SKPKD.Penerbit Salemba Empat 2012.

Darise, Pengelolaan Keuangan Daerah.Edisi Kedua.

Himpunan Peraturan Perundang-undangan Pegawai Negeri Sipil. (Penerbit Fokus Media). Website:www.fokusmedia.co.id.

Harahap,Sofyansyafri. 2005. Teori Akuntansi. Penerbit PT. Raja Grafindo Persada: Jakarta.

Kieso Weygandt Warfield,Intermediate Accounting.Volume 1IFRS Edition.

Mahmudi, Analisis Laporan Keuangan Pemerintah Daerah.

Muhammad. 2002. Balkaoui. 2000.American Institute of Certified Public Accountant.

Mulyadi, 2001.Sistem Akuntansi, Edisi Ke-5, Penerbit Bagian Penerbitan. 
Niswonger, C. Rollin, et.al 1999. Prinsip-Prinsip Akuntansi Edisi 19 Jilid 1. Penerbit Erlangga: Jakarta.

Peraturan Menteri Dalam Negeri No 13 Tahun 2006. Tentang Pedoman Pengelolaan Keuangan Daerah,Jakarta.

Peraturan Pemerintah No 24 Tahun 2005. Tentang Standar Akuntansi Pemerintahan.

Revrisond, Baswir. 2000. Akuntansi Pemerintahan Indonesia. Yogyakarta: BPFE. Sekolah Tinggi Ilmu Ekonomi YKPN, Yogyakarta.

Sugiarto dkk. 1999. Pengantar Akuntansi I. Penerbit Universitas Terbuka: Jakarta.

Sukiyoprapti, 2007. Pegawai Negeri Sipil. Yogyakarta Universitas Muhammadiyah.

Soemarsono S.R 2002. Akuntansi Pengeluaran Kas.

Warren et al. 2005. System Informasi Akuntansi. Bandung.

Weygandt Kimmel Kieso,Financial Accounting. IFRS Edition. 